\title{
Типологія водної рослинності Українського Розточчя: клас Potametea Klika in Klika et Novak 1941
}

\author{
Руслана Данилик, Віктор Скробала
}

Національний лісотехнічний університет України, м. Львів, Україна

Адреса для листування: druslana@ukr.net

Отримано: 07.03.19; прийнято до друку: 07.04.19; опубліковано: 28.06.19

Резюме. У статті наведено типізацію місцезростань водної рослинності класу Potametea Українського Розточчя. Угруповання цього класу відіграють важливу роль у процесах евтрофізації та заростання прісних водойм, слугують проміжною ланкою в ряді сукцесійного переходу водної рослинності в прибережно-водну. Типізація місцезростань водної рослинності класу Potametea дає змогу прогнозувати напрям проходження сукцесій, зумовлених природними й антропогенними чинниками. Типізацію місцезростань виконували методами добування даних на основі фітоіндикаційної оцінки екологічних режимів біотопів за сімома параметрами: $\mathrm{L}$ - освітленість, T - термічний режим, $\mathrm{K}$ - континентальність, F - режим зволоженості, R - кислотність, N - уміст азоту, S - уміст солей, балів. Дослідження охоплювали три основні етапи: вивчення структури взаємного розміщення фітоценозів у багатовимірному просторі екологічних параметрів, математичне моделювання структури та перевірка математичної моделі. Для екотопів рослинності класу Potametea Українського Розточчя характерний порівняно вузький діапазон варіювання значень екологічних параметрів. Найбільшу значущість для диференціації місцезростань мають параметри водного режиму (глибина водойм) і вміст азоту. У спрощеному вигляді типологічну схему водної рослинності класу Potametea можна представити у вигляді трикутника, у центрі якого розміщена асоціація Hydrocharitetum morsus-ranae, а на вершинах Ceratophylletum demersi, Potametum natantis і Hottonietum palustris. У тривимірному просторі типологічна схема має вигляд трикутної піраміди, вершиною якої є асоціація Ranunculo-Sietum erecto-submersi. Малопоширені фітоценози Ranunculetum circinati та Nupharo-Nymphaeetum albae займають периферію екологічного простору водної рослинності.

Ключові слова: Українське Розточчя, багатовимірна типологія, математичне моделювання, Potametea.

\section{Typology of Ukrainian Roztochia Aquatic Vegetation: Class Potametea Klika in Klika et Novak 1941}

\author{
Ruslana Danylyk, Vicnor Skrobala \\ National University of Forestry and Wood Technology of the Ukraine, Lviv, Ukraine \\ Correspondence: druslana@ukr.net
}

Abstract. The habitats typology of aquatic vegetation from the class Potametea Klika in Klika et Novak
941 in Ukrainian Roztochia is covered in this article. Communities of this class play an important role in the
processes of eutrophication and overgrown of fresh water basins, serving as an intermediate link in a series of
successional transition of aquatic vegetation to coastal water one. Typization of the water vegetation location of
he Potametea class allows one to predict the course of successions caused by natural and anthropogenic factors.
Typology of habitats was studied by methods of obtaining data from phytoindicational score assessment of the
environmental habitats' regimes on seven parameters: $\mathrm{L}-$ light, $\mathrm{T}-$ thermal mode, $\mathrm{K}-$ continentality, $\mathrm{F}-$
moisture mode, $\mathrm{R}$ - acidity, $\mathrm{N}-$ nitrogen, $\mathrm{S}-$ salt content. The research included three main stages: studying the
tructure of plant communities in the relative position of multidimensional space of environmental parameters,
mathematical modeling of the structure and verification of mathematical model. For the vegetation ecosystems
of the Potametea class of Ukrainian Roztochia, a relatively narrow range of variations in the values of
C Данилик Р., Скробала В., 2019 
environmental parameters is determined. The parameters of water regime (depth of reservoirs) and nitrogen content are the most important for the differentiation of places. In a simplified form, the typological scheme of aquatic vegetation of the Potametea class may be represented as a triangle in the center of which is the association Hydrocharitetum morsus-ranae, and the associations Ceratophylletum demersi, Potametum natantis and Hottonietum palustris are on the vertices. In a three-dimensional space, the typological scheme has the form of a triangular pyramid, the apex of which is the association Ranunculo-Sietum erecto-submersi. The less common associations such as Ranunculetum circinati and Nupharo-Nymphaeetum albae occupy the periphery of the ecological space of aquatic vegetation.

Key words: Ukrainian Roztochia, multidimensional typology, mathematical modeling, Potametea.

\section{Ветуп}

Математичне моделювання біологічних систем дає змогу визначити положення на типологічній схемі різних синтаксонів рослинності, зокрема й водної. Завдяки багатовимірній типології фітоценологічну інформацію можна трактувати в категоріях напряму та відстані в багатовимірному просторі ознак, вирішуючи питання динаміки водної рослинності, взаємозв'язків з іншими типами рослинності й екологічного прогнозування. Так, напрям проходження антропогенних сукцесій водної рослинності часто пов'язаний зі зменшенням рівня грунтових вод $\mathrm{i}$ формуванням інших типів рослинності. [1].

Клас Potametea Klika in Klika et Novak 1941 об'єднує угруповання прикріплених гідатофітів із плаваючими на поверхні або зануреними в товщу води листками, що поширені в мезотрофних i мезоевтрофних водоймах iз піщаними та мулистими донними відкладами на глибині 50-250 (до 600) см [2, 3, 4]. Угруповання класу відіграють важливу роль у процесах евтрофізації й заростання прісних водойм, слугують проміжною ланкою в ряді сукцесійного переходу водної плаваючої рослинності в прибережно-водну $[5,6,7]$. Типізація місцезростань водної рослинності класу Potametea дає змогу прогнозувати напрям проходження сукцесій, зумовлених природними та антропогенними чинниками.

\section{Об'єкти й методи досліджень}

Типізацію місцезростань водної рослинності Українського Розточчя класу Potametea виконували методами добування даних [8] на основі фітоіндикаційної оцінки екологічних режимів біотопів за сьома параметрами: $\mathrm{L}$ - освітленість, T - термічний режим, K - континентальність, $\mathrm{F}$ - режим зволоженості, $\mathrm{R}$ - кислотність, $\mathrm{N}$ - уміст азоту, $\mathrm{S}$ - уміст солей, балів [9]. Крім власних описів, використовували також дані літературних джерел $[10,11]$. Назви та автори синтаксонів подано згідно із синтаксономічною схемою рослинності Українського Розточчя [11].

Кожне рослинне угруповання можна представити у вигляді точки в багатовимірному просторі ознак, координати якої відповідають значенням параметрів екологічних режимів [8]. У цьому випадку подібність фітоценозів за сукупністю екологічних параметрів можна визначити на основі відстаней між точками. Суть подальшої математичної процедури полягає у виділенні екологічного простору асоціацій, оцінці відмінностей між ними. Порівняльну оцінку місцезростань здійснювали методами одновимірного статистичного аналізу, пошуку логічних закономірностей на основі алгоритму CART i канонічного дискримінантного аналізу [8, 12]. Перевірку математичної моделі виконували на основі порівняльної оцінки положення фітоценозів на осях варіювання (багатовимірної ординації) із результатами геоботанічних досліджень та даними літературних джерел [3, 5, 7, 9-11].

\section{Результати досліджень}

Угруповання водної рослинності формуються в умовах більш однорідного за фізикохімічними властивостями середовища, ніж фітоценози суходільних місцезростань [3]. Незважаючи на досить вузький діапазон варіювання значень екологічних параметрів рослинності класу Potametea за шкалами Г. Елленберга (табл. 1), результати дисперсійного аналізу свідчать про достовірну значущість у диференціації місцезростань усіх без винятку екологічних чинників. Мінімальну значущість мають параметри континетальності клімату та засолення, а максимальну - уміст азоту й режим зволоження. Діапазон варіювання середніх значень екологічних параметрів асоціацій класу Potametea відображений у табл. 1 .

Пошук логічних закономірностей у системі координат екологічних параметрів дав змогу встановити такі діагностичні правила для типізації місцезростань водної рослинності класу Potametea: 
Типологія водної рослинності Украӥнського Розточчя: клас Potametea Klika in Klika et Novak 1941

Stratiotetum aloides: $\mathrm{R}>7,40 ; \mathrm{N} \leq 6,79 ;$

Ceratophylletum demersi: $\mathrm{R}>7,40 ; \mathrm{N}>6,79$;

Ranunculetum circinati: $\mathrm{R} \leq 7,40 ; \mathrm{S}>0,59$;

Hydrocharitetum morsus-ranae: $\mathrm{R} \leq 7,40$;

$\mathrm{N}>5,88 ; \mathrm{L}>6,65 ; \mathrm{F} \leq 11,40$;

Elodeetum canadensis: $\mathrm{R} \leq 7,40 ; \mathrm{N}>5,88$;

$\mathrm{L}>6,65 ; \mathrm{F}>11,40$;

Potametum natantis: $\mathrm{R} \leq 7,40 ; \mathrm{N} \leq 5,88 ; \mathrm{R}>6,85$;

Polygonetum natantis: $\mathrm{R} \leq 7,40 ; \mathrm{N} \leq 5,88$;

$\mathrm{R} \leq 6,85 ; \mathrm{F} \leq 11,46$;

Hottonietum palustris: $\mathrm{R} \leq 7,40 ; \mathrm{N} \leq 5,88$;

$\mathrm{R} \leq 6,85 ; \mathrm{F}>11,46$ тощо.

На основі пошуку логічних закономірностей не вдалося чітко окреслити межі типів місцезростань асоціацій: Myriophylletum verticillati, Nupharo-Nymphaeetum albae, Nupharo-Nymphaeetum candidae, Potametum lucentis, Ranunculetum fluitantis $i$ RanunculoSietum erecto-submersi.

Аналіз залежності між екологічними параметрами місцезростань указує на наявність середнього зв'язку між окремими змінними (рис. 1). Так, для параметрів уміст азоту й кислотність коефіцієнт кореляції $\mathrm{r}=0,63$; уміст азоту та освітленість $\mathrm{r}=-0,61$; параметр водного режиму зв'язаний із температурою $(\mathrm{r}=0,54)$ й освітленістю $(\mathrm{r}=-0,51)$. Отже, для багатовимірної ординації водної рослинності Українського Розточчя класу Potametea характерна наявність певною мірою впорядкованої структури, що дає підстави для математичної процедури зменшення вимірності простору та побудови типологічної схеми.
Результати математичного моделювання можна представити такими формулами:

Root $_{1}=0.99 \times \mathrm{L}+3.03 \times \mathrm{T}-1.19 \times \mathrm{K}+2.44 \times \mathrm{F}-1.74 \times$ $\mathrm{R}+2.42 \times \mathrm{N}-0.25 \times \mathrm{S}-50.14$;

Root $_{2}=-0.46 \times \mathrm{L}-3.13 \times \mathrm{T}+0.47 \times \mathrm{K}-1.62 \times \mathrm{F}+$ $1.62 \times \mathrm{R}+1.36 \times \mathrm{N}+2.05 \times \mathrm{S}+17.92$;

Root $_{3}=-2.07 \times \mathrm{L}-3.70 \times \mathrm{T}+1.06 \times \mathrm{K}+2.05 \times \mathrm{F}-$ $0.24 \times \mathrm{R}-1.00 \times \mathrm{N}+4.41 \times \mathrm{S}+14.68$,

де $\operatorname{Root}_{i}$ - канонічні відмітки рослинних угруповань, осі типологічної схеми; L, T, K, F, $\mathrm{R}, \mathrm{N}, \mathrm{S}$ - значення екологічних параметрів місцезростань (освітленість, термічний режим, континентальність, режим зволоженості, кислотність, уміст азоту, уміст солей).

Дві канонічні функції забезпечують 57,2 \%, а три канонічні функції - 73,3 \% загальної дисперсії, тому для багатьох цілей аналізу достатньо використовувати тільки тривимірну проекцію початкової матриці даних (семи вимірного простору). Результати математичного моделювання відображено на рис. 1, 2 .

Значення першої канонічної функції залежать, передусім, від температурного режиму (коефіцієнт кореляції $\mathrm{r}=0,70$ ), водного режиму $(\mathrm{r}=0,76)$, умісту азоту $(\mathrm{r}=0,70)$ та освітленості $(\mathrm{r}=-0,43)$ (рис. 1). Мінімальними значеннями цієї функції характеризуються асоціації Potametum natantis i Ranunculo-Sietum erectosubmersi, а максимальними - Ceratophylletum demersi (рис. 2). Угруповання Ranunculo-Sietum erecto-submersi характеризуються найменшим рівнем обводнення. Вони формуються в добре освітлених мезотрофних водоймах і старих

Екологічні параметри місцезростань водної рослинності класу Potametea

Таблиияя 1

\begin{tabular}{|l|c|c|c|c|c|c|c|}
\hline \multirow{2}{*}{\multicolumn{1}{|c}{ Синтаксон }} & \multicolumn{6}{|l}{ Екологічні параметри місцезростань, балів } \\
\cline { 2 - 8 } & $\mathbf{L}$ & $\mathbf{T}$ & $\mathbf{K}$ & $\mathbf{F}$ & $\mathbf{R}$ & $\mathbf{N}$ & $\mathbf{S}$ \\
\hline 1. Potametum lucentis & 6.54 & 5.92 & 4.10 & 11.60 & 6.50 & 6.58 & 0.28 \\
\hline 2. Elodeetum canadensis & 6.94 & 6.00 & 4.60 & 11.60 & 7.06 & 6.77 & 0.26 \\
\hline 3. Ceratophylletum demersi & 6.35 & 6.48 & 4.12 & 11.79 & 7.58 & 7.29 & 0.26 \\
\hline 4. Ranunculetum circinati & 6.45 & 5.88 & 4.66 & 11.67 & 6.97 & 7.14 & 0.73 \\
\hline 5. Hydrocharitetum morsus-ranae & 6.96 & 5.90 & 4.10 & 10.98 & 6.86 & 5.96 & 0.20 \\
\hline 6. Stratiotetum aloides & 7.02 & 6.00 & 4.71 & 11.00 & 7.73 & 6.11 & 0.15 \\
\hline 7. Potametum natantis & 6.55 & 5.38 & 4.61 & 11.03 & 6.97 & 5.58 & 0.27 \\
\hline 8. Myriophylletum verticillati & 5.85 & 5.97 & 4.67 & 11.76 & 6.95 & 7.24 & 0.14 \\
\hline 9. Nupharo-Nymphaeetum albae & 7.07 & 6.13 & 4.12 & 11.10 & 6.99 & 6.27 & 0.27 \\
\hline 10. Nymphaeetum candidae & 7.37 & 5.96 & 4.79 & 11.17 & 5.63 & 5.23 & 0.17 \\
\hline 11. Polygonetum natantis & 6.87 & 5.90 & 3.97 & 11.11 & 6.21 & 4.73 & 0.13 \\
\hline 12. Hottonietum palustris & 7.04 & 5.92 & 4.50 & 11.54 & 5.75 & 4.98 & 0.20 \\
\hline 13. Ranunculetum fluitantis & 6.89 & 5.78 & 4.05 & 11.55 & 7.27 & 6.45 & 0.30 \\
\hline 14. Ranunculo-Sietum erecto-submersi & 7.13 & 5.29 & 3.49 & 9.66 & 6.71 & 6.40 & 0.08 \\
\hline
\end{tabular}


Науковий вісник Східноєвропейського національного університету імені Лесі Українки. Серія: Біологічні науки, 2019, 3 (387)

каналах глибиною до 0,5 м [11]. Ceratophylletum demersi - асоціація затінених водойм, яка може формуватися в малопрозорих водах, досягаючи глибини 2 м.

Значення другої канонічної функції залежать від кислотності (коефіцієнт кореляції $\mathrm{r}=0,74$ ) та вмісту азоту $(\mathrm{r}=0,69)$, меншою мірою - від освітленості $(\mathrm{r}=-0,37)$ і засолення $(\mathrm{r}=0,31)$ (рис. 1). Мінімальними значеннями цієї функції характеризуються асоціації Polygonetum natantis, Hottonietum palustris i Nymphaeetum candidae, а максимальними - Ceratophylletum demersi, Ranunculetum circinati, RanunculoSietum erecto-submersi (рис. 2). Названі асоціації певною мірою відображають екологічний ряд зростання $\mathrm{pH}$ i вмісту азоту. Так, Nymphaeetum candidae формується в більш оліготрофних умовах, не переносить карбонатних вод, часто трапляється в каналах, прокладених у торфово-болотних грунтах iз низьким рівнем $\mathrm{pH}$ [11]. Дно водойми, де формується асоціація Hottonietum palustris, також часто торфове. Ranunculetum circinati на Розточчі трап-
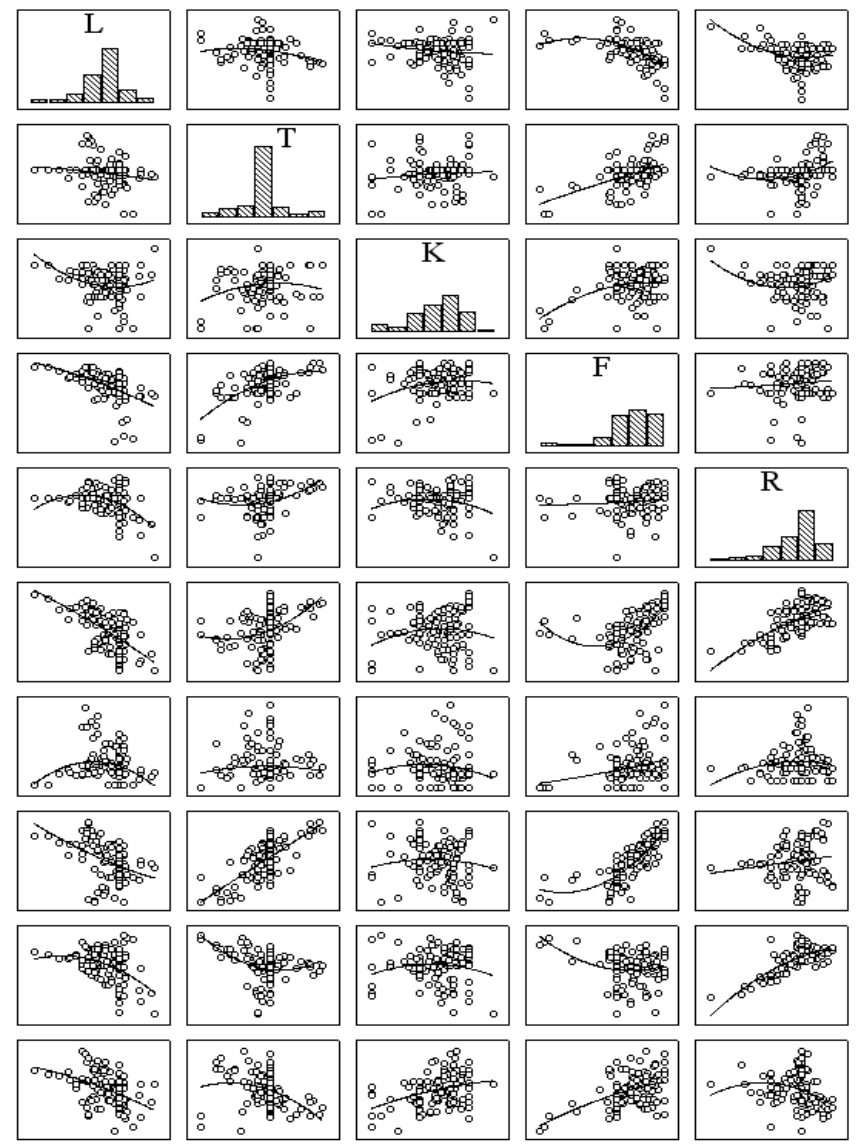

ляється тільки в евтрофних водоймах 3 органічним дном [11].

Третя канонічна функція характеризується складною комбінацією екологічних факторів. Їі значення залежать від умісту солей $(\mathrm{r}=0,48)$, водного режиму $(\mathrm{r}=0,46)$, освітленості $(\mathrm{r}=-0,43)$, континентальності $(\mathrm{r}=0,37)$, термічного режиму (r=-0,35), кислотності (r=-0,26). Мінімальними значеннями цієї функції характеризується асоціація Ranunculo-Sietum erecto-submersi, a максимальними - Ranunculetum circinati i Potametum natantis.

Кореляція між екологічними параметрами місцезростань виступає істотною проблемою геоботанічних досліджень. Тому для пояснення особливостей поширення водної рослинності класу Potametea для всіх асоціацій ми визначали відстань Махаланобіса - багатовимірний аналог відстані Евкліда із врахуванням кореляції між екологічними параметрами [8]. У результаті обчислень нами встановлено, що асоціація Hydrocharitetum morsus-ranae формує ядро водної рослинності класу Potametea в умовах Розточчя. Це досить поширена
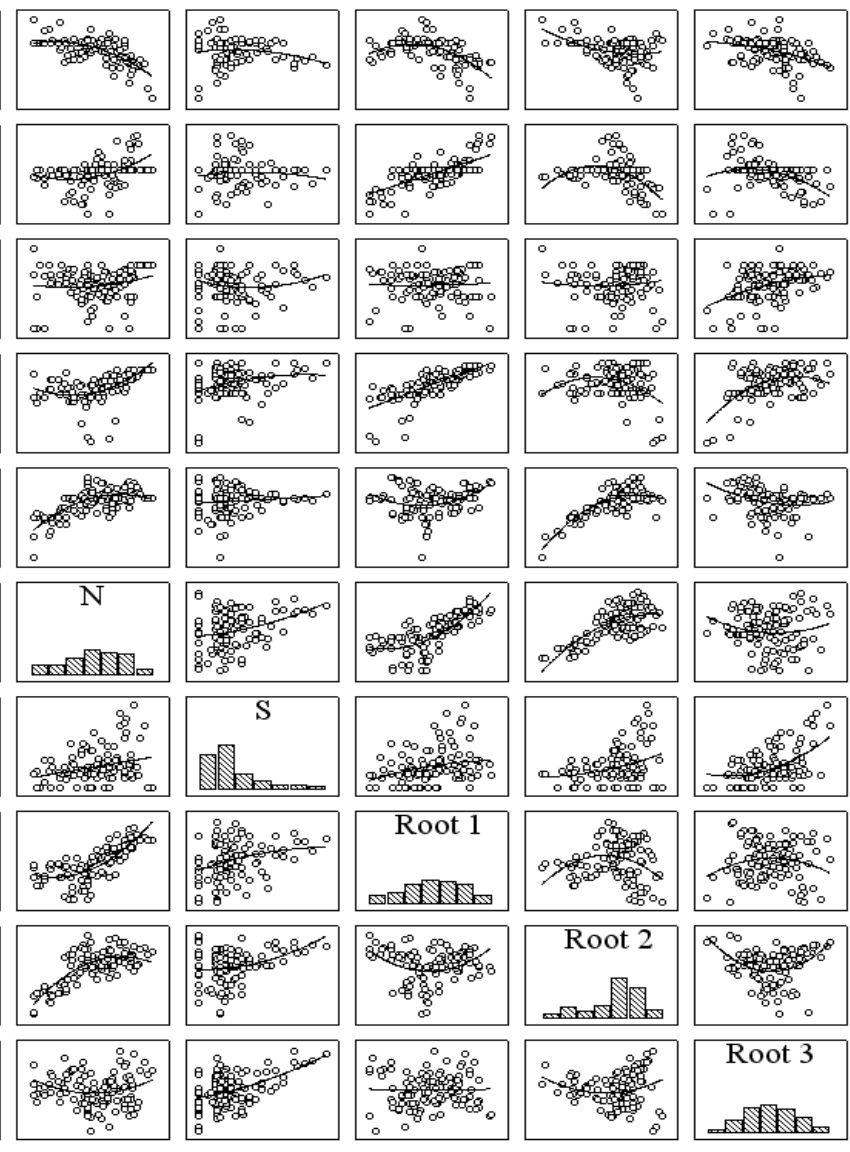

Рис. 1. Діаграма залежності між екологічними параметрами місцезростань водної рослинності класу Роtатетеа та комплексними градієнтами середовщща:

Примітка. $L$ - освітленість, $T$-термічний режим, $K$-континентальність, $F$-режим зволоженості, $R$-кислотність, $N$-уміст азоту, $S$-уміст солей, балів; Roоt $_{i}$ - комплексні градієнти середовища, осі типологічної схеми. 

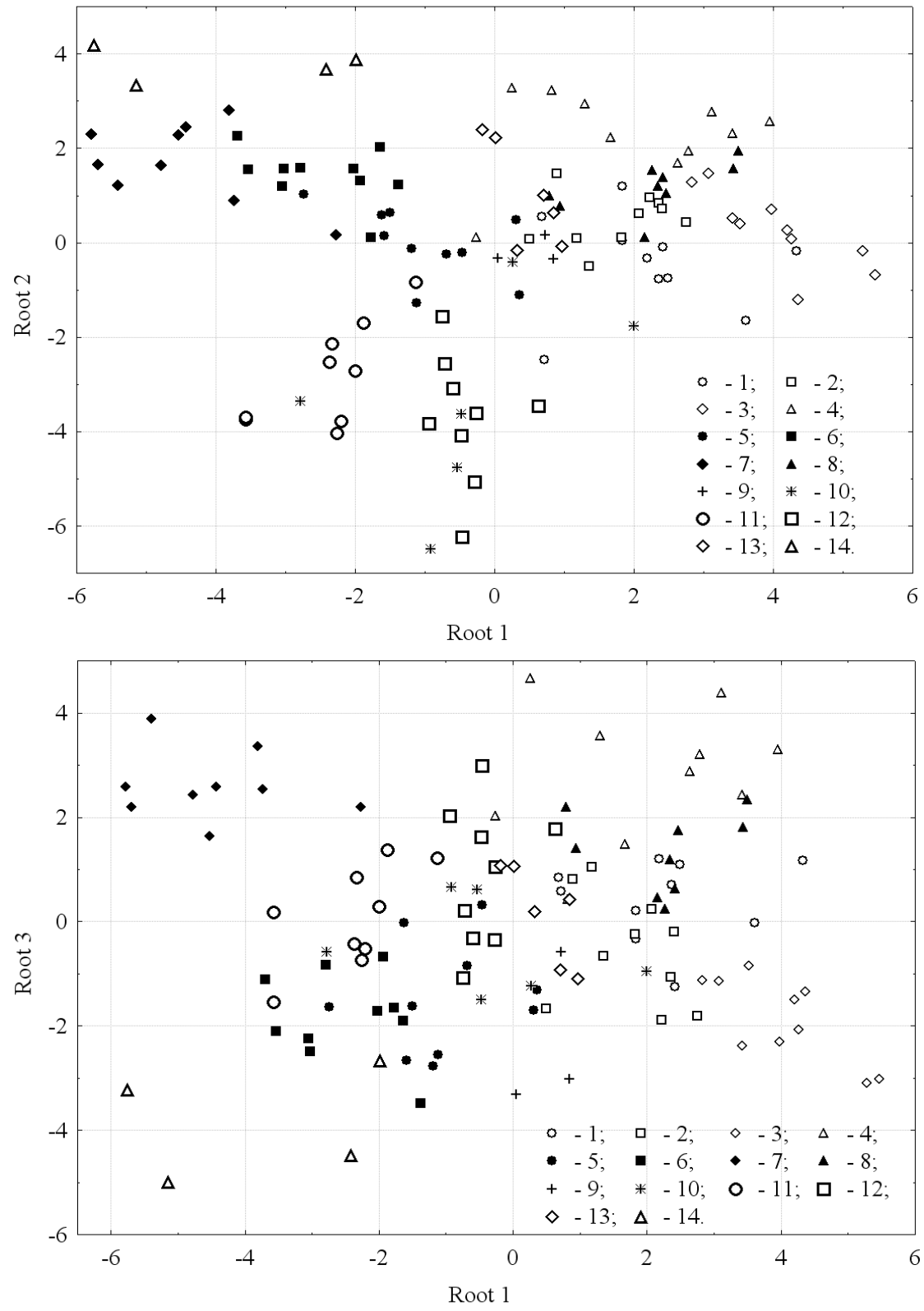

Рис. 2. Типологічна схема водної рослинності класу Potametea: числова нумерація синтаксонів відповідає таблииі

асоціація водної рослинності регіону. Найбільш віддаленою за сукупністю екологічних параметрів є асоціація Ranunculo-Sietum erectosubmersi, характеристику якої наведено вище.

У спрощеному вигляді типологічну схему водної рослинності класу Potametea можна представити у вигляді трикутника, у центрі якого розміщена асоціація Hydrocharitetum morsus-ranae, а по кутах - Ceratophylletum demersi, Potametum natantis i Hottonietum palustris (рис. 2). У тривимірному просторі типологічна схема має вигляд трикутної піраміди, вершиною якої є асоціація RanunculoSietum erecto-submersi.

Звичайно, закономірності формування водної рослинності класу Potametea $€$ набагато складнішими. У своїх дослідженнях ми обмежилися тривимірною проекцією семивимір- ного простору екологічних чинників, у той час як значущими $\epsilon$ п'ять комплексних градієнтів середовища. Але навіть у спрощеному варіанті типологічної схеми можна відзначити низку особливостей. Так, малопоширена в регіоні асоціація Ranunculetum circinati займає периферію екологічного простору (рис. 2), а поширені асоціації Potametum lucentis й Elodeetum canadensis на типологічній схемі займають його центр. Рідкісна асоціація Nupharo-Nymphaeetum albae займає периферію екологічного простору в системі координат першої та третьої канонічних функцій (рис. 2).

Завдяки багатовимірній типології фітоценологічну інформацію можна трактувати в категоріях напряму та відстані в багатовимірному просторі ознак, вирішуючи питання динаміки водної рослинності, взаємозв'язків 3 
іншими типами рослинності й екологічного прогнозування. Так, напрям проходження антропогенних сукцесій водної рослинності часто пов'язаний зі зменшенням рівня грунтових вод i формуванням інших типів рослинності. Математичне моделювання дає змогу визначити положення на типологічній схемі різних асоціацій або класів рослинності. Обчислення показують, що водна рослинність класу Potametea в умовах Розточчя часто виступає первинною ланкою в сукцесійній схемі рослинності: водойми $\rightarrow$ болота $\rightarrow$ луки $\rightarrow$ чагарники $\rightarrow$ ліси. Якщо класу рослинності Potametea відповідають координати $(0,00 ; 0,00$; $0,00)$, то іншим класам рослинності - такі координати на типологічній схемі: Scheuchzerio-Caricetea $(-11,02 ;-1,83 ;-0,64)$, OxycoccoSphagnetea $(-11,05 ;-5,08 ; 2,68), \quad$ Alnetea glutinosae $(-11,03 ; 3,03 ;-2,94)$, Querco-Fagetea $(-18,33 ; 9,21 ;-5,06)$, Vaccinio-Piceetea $(-20,18$; 2,27; -4,05), Lemnetea minoris $(-0,14 ; 0,66 ;-0,05)$, Phragmitetea (-6,18; 3,06; -3,15), Koelerio glaucae-Corynephoretea (-22,47; 3,82; -13,80), Festuco-Brometea $(-25,11 ; 8,08 ;-15,62)$, NardoCallunetea (-19,01; 0,88; -11,49), Asplenietea rupestris $(-23,95 ; 10,11 ;-6,35)$, TrifolioGeranietea sanguinei $(-23,73 ; 7,62 ;-14,06)$, Molinio-Arrhenatheretea (-13,71; 7,18; -8,87), Bidentetea tripartiti $(-4,37 ; 5,58 ;-10,14)$, Artemisietea vulgaris $(-14,40 ; 10,91 ;-14,85)$, Agropyretea intermedio-repentis (-18,42; 10,89; -14,64), Epilobietea angustifolii (-15,77; 8,15; $-11,22)$, Stellarietea mediae $(-13,93 ; 8,31 ;-13,96)$.

Сукцесійні взаємозв'язки синтаксонів водної, прибережно-водної, болотної та лісової рослинності можна охарактеризувати розміщенням на типологічній схемі асоціацій: Myriophylletum verticillati (2,25; 1,07;1,24), Ceratophylletum demersi $(4,04 ; 0,26 ;-1,88)$, Stratiotetum aloides $(-2,48 ; 1,44 ;-1,82)$, Scirpetum lacustris $(-0,89 ; 2,17 ;-1,96)$, Typhetum latifoliae (-2,34; 4,71; -2,74), Phragmitetum australis (-6,03; $4,81 ;-3,21)$, Caricetum elatae $(-4,55 ; 0,01 ;-3,66)$, Caricetum lasiocarpae (-11,14; -1,27; -0,03), Ledo-Sphagnetum magellanici (-11,05; -5,08; 2,68), Sphagno squarrosi-Alnetum $(-9,00 ; 2,00$; $-3,11)$, Ribeso nigri-Alnetum $(-10,40 ; 3,86 ;-2,56)$, Molinio-Pinetum (-16,15; -1,48; -1,63), Vaccinio uliginosi-Pinetum $(-14,53 ;-2,98 ; 0,08)$.

\section{Висновки}

Для екотопів рослинності класу Potametea характерний порівняно вузький діапазон варіювання значень екологічних параметрів. Найбільшу значущість для диференціації місцезростань мають параметри водного режиму (глибина водойм) i вміст азоту. У спрощеному вигляді типологічну схему водної рослинності класу Potametea можна представити у вигляді трикутника, у центрі якого розмішена асоціація Hydrocharitetum morsus-ranae, а по кутах - Ceratophylletum demersi, Potametum natantis i Hottonietum palustris. У тривимірному просторі типологічна схема має вигляд трикутної піраміди, вершина якої - асоціація Ranunculo-Sietum erectosubmersi. Малопоширені фітоценози Ranunculetum circinati та Nupharo-Nymphaeetum albae займають периферію екологічного простору водної рослинності.

\section{Література}

1. Данилик, Р. М.; Скробала, В. М; Типологія водної рослинності Українського Розточчя: клас Lemnetea R.Tx. 1955. Біологічні системи; 2017, 9(1), c 81-86.

2. Rodwell, J. S. British Plant Communities. Aquatic Communities Swamps and Tall-Herb Fens. Cambridge: Univer. Press, 1995; V. 4, 283 p.

3. Дубина, Д. В. Вища водна рослинність. Рослинність України. Фітосоціоцентр: Київ, 2006; $412 \mathrm{c}$.

4. Chytrý, M. (ed.) Vegetace České republiky 3. Vodni a mokradni vegetace. Vegetation of the Czech Republic, 3. Aquatic and wetland vegetation. Academia: Praha, 2011; 827 p.

5. Биоиндикация загрязнений наземных екосистем. Под ред. Р. Шуберта. Мир: Москва, 1988; $348 \mathrm{c.}$

6. Дубына, Д. В.; Гейны, С.; Гроудова, 3. и др. Макрофить - индикаторы изменений природной средыл. Наук. думка: Киев, 1993; 434 с.

7. Соломаха, В. А. Синтаксономія рослинності Украӥни. Третє наближення. Фітосоціоцентр: Київ, 2008; 296 c.

8. Дюк, В.; Самойленко, А. Data Mining: учебн.курс. Питер: Санкт-Петербург, 2001; 368 с.

9. Ellenberg, H.; Weber, H. E.; Dull, R. et al. Zeigerwerte von Pflanzen in Mitteleuropa. Scripta geobot; 1992, Vol. 18, $258 \mathrm{~S}$.

10. Ткачик, В. П. Рослинність заповідника «Розточчя»: класифікачія методом Браун-Бланке. НТШ: Львів, 1998; 198 с.

11. Сорока, М. І. Рослинність Украӥнського Розточчя. Світ: Львів, 2008; 434 с.

12. Шитиков, В. К.; Розенберг, Г. С.; Зинченко, Т. Д. Количественная гидроэкология: методы системной идентификации. ИЭВБ РАН: Тольятти, 2003; 463 c. 